\title{
Cultural syndromes in Koreans and others - a medical anthropology in search for resolution and prevention
}

\author{
Sok Kyu Lee $e^{1, \mathbb{x}}$ \\ ${ }^{1}$ Geriatric care, Ara Yoyang Hospital, Jeju City
}

\begin{abstract}
Korean Physicians encounter often the patients with cultural syndromes. This paper surveys those cultural syndromes in Korea, contrasted with those in other countries in five different domains; socio-cultural, sexual, psychological, psychosomatic and religio-spiritual. I discovered three natural consequences if not intervened; 1 ) healed and readjusted, 2) paradigmatically shifted for the better results and 3) mal-adjustment for the worse. In the hope to let the culture shifted toward better one, I propose to allow our Koreans to be educated, inspired by Park Wansoe's novel; 'Dreaming in an Incubator (꿈꾸는 인큐베이터)'.
\end{abstract}

Key words: Cultural syndrome, Hwabyung, Korean culture, Forgiveness, Education

\section{INTRODUCTION}

Doctors are to be familiar to the nature of illnesses, not only from biological derangements, but also those from cultural maladjustment. The latter includes mental illnesses, psychological dysfunctions, interpersonal maladjustment in daily individual life situation, religio-spiritual problems, loss of meaning of life, and hopelessness in socio-cultural situation, with which our patients often present to our clinics. Culture is an integrated system of learned behavior patterns, which are characteristic of the members of a society and which are not a result of biological inheritance according to Hoebal. ${ }^{1)}$

\section{CULTURAL SYNDROME: A SURVEY}

In this survey, my paper will focus on the cultural syn-

Received: December 4, 2019; Revised: December 12, 2019; Accepted: December 13, 2019 $\checkmark$ Correspondence to : Sok Kyu Lee

Geriatric care, Ara Yoyang Hospital, Hanbook-ro 309 (Ara 1-dong), Jeju City, Republic of Korea

Tel: 82-64-729-6000, FAX: 82-64-722-7100

E-mail: sokkyulee@gmail.com dromes (CS) mainly in Korean culture compared to others. CS was recognized first as a mental illness since DSMIV 1994. I will discern CS in five domains; socio-cultural, sexual, psychological, psychosomatic and religio-spiritual. My classification of CS is inclusive for those socio-cultural conditions in addition to those of the psychological one in DSM. In order to provide better understanding, I will use Korean and English terms for my bilingual readers. This systemic approach would help Korean clinicians assist our patients with CS. At the end, three ways to result from these predicaments toward better or worse resolutions are to be proposed. Not only we are able to treat these conditions but also I hope in our ability to prevent these maladies by readjusting and improving our culture itself. I discovered a possibility of the ways to heal in 'Dreaming in an Incubator (꿈꾸는 인큐베이터)' by Park Wansoe, 1993. ${ }^{2)}$

\section{Socio-cultural domain}

Hwa-Byung (홧병火病) is one of the Korean cultural syndromes, first included as a culture-bound syndrome (DSM5). This was most studied and was defined as "clusters of symptoms and attributions that tend to co-occur among individuals in Korean cultural group, communities or con- 
text" by Lewis-Fernandez. ${ }^{3,4)}$ Clinical manifestations include anger, feeling of oppression, depression and anxiety. In Korean folk medicine, it has been known as sobbing (속 병), Shimyakjeung (심약증), Eekul (억울), Boon (분), Wonhan (원한怨恨), Gobugaldeungbyung (고부갈등병姑婦葛藤 病) and others, originated from accumulated injustice and oppression in family (Hwa-Byung) or social life (Han, 한 恨). The latter Han refers often people's anger from tragic national collective oppression, Han, Wonhan, such as from the Korean War and the 4. 3 Jeju Uprising. I elucidate on Han later in the section of discussion. Similar psychosomatic conditions are found in other Asian countries (Anger syndrome) and in U.S. with Caribbean culture (ataque de nervios).

For Korean cultural syndromes in Socio-cultural domain, I would include bullying (왕따), Entrance examination stress (입시병入試病), Extravagance (낭비병浪費病), Fame seeking disease (명성병名聲病), One-sided love (편애병偏愛 病), Loneliness and Friendlessness (외롬병), Singleness (독 신병獨身病), Joblessness (무직병無職病), Hopelessness (실 망병失望病), even Suicide (자살병自殺病) in this category, because they are newly found in modern Korean society. In American Appalachian culture, backache in men and headache in women are recognized as cultural syndromes. In American Indians, I have discovered during my stay in the reservations that Soul Loss, Bad Spirit possession and Anti-white hatred and fear are known in the native population. In Mexican folk medicine, I draw your attention to susto (Frightening), empacho (indigestion), soul-loss (loss of reasoning), mal de ojos (bad spirit due to staring), caida de mollera (sunken fontanel), and envidia (envy-provoking) among cultural syndromes. It is remarkable that envidia of Mexican folk medicine is a cultural syndrome, which afflicts a person, who provokes envy of the viewers by showing-up his expensive possessions.

\section{Sexual domain}

Broken heartedness (상사병相思病) is well known in fictions and in folk songs; Dream (꿈 - 이광수) in the former and Arirang (아리랑) in the latter. Koro is a brief and delusion of penis shrinkage and retraction into the body found among Asian cultures. I would include concupiscence (sexual greed, 외도) which is one of the two original sins (pride is the other) by St. Augustine. It was not uncommon in late Lee Dynasty among Yang-ban classes.

\section{Psychological domain}

During rapid financial advancement in modern Korea, the most of affluent group become patients of superior- ity complex (자만병自滿病) and in other hands, the poor people suffer from inferiority complex (가난병). Furthermore, they blame the consequence on the others, as G Scott Peck describes as a character disorder, 'Blaming-on-others'. 5)

\section{Psychosomatic domain}

In addition to Hwa-Byung, Korean students suffer from adjustment disorders in childhood due to stresses from the highly competitive entrance examinations of the Korean universities revealing as stuttering, tics and Tourette's disease. Consequently they become depressed, leading to suicide when they are not able to overcome the dual crises according to the theory of the Identity Crisis of Erikson. ${ }^{6}$

\section{Religio-spiritual domain}

Among religio-spiritual domain, Korean shamans become initiated to a shaman by having a "Possession by Spirits" (신들림, 무당병巫堂病). Over-belief results in presumption and hopelessness causes despair according to $\mathrm{Marcel}^{7)}$ and the real examples are found by the tragic events of coerced mass suicide led by Koresh ${ }^{8)}$ and Jones ${ }^{9)}$ in recent American culture. Loss of Meaning of Life (loss of logos) of Frankl ${ }^{10)}$ may lead to depression ending to suicide. Though known as Elijah complex in Western literature, an extreme disappointment and loneliness, and failure, which specifically follows a time of great success is found in recent Korean society and politics. In Latin American culture, hex (저주병詚呪病) and in Navajo culture, ghost sickness are similarly found in Korean Shamanism. Historically, bewitchedness and Inquisitions; Medieval Inquisition (1184 16th century); the Spanish Inquisition (1478 1834); the Portuguese Inquisition (1536 1821); and the Roman Inquisition $(1542 \sim \mathrm{c} .1860)$ are tragic examples of Catholicism.

\section{DISCUSSION}

Then, do we have any light of resolution at the end of Korean cultural syndromes for, you may ask. I argue that I believe there is some theoretical possibility. Allow me to explicate. Han and its resolution have been discerned ethically in detail by Andrew Sung Park, ${ }^{11)}$ a Christian ethicist of U.S and Kang Bong Soo ${ }^{12)}$ a professor at Department of Ethics, Jeju National University. First, I will dwell on the ways to get the resolutions by these two ethicists. Then, I invoke the literally and fictional proposal by Lee Chung Joon, ${ }^{13)}$ who has searched in his novel, 'A Story of Worms 
(벌레이야기)'.

In his book, The Wounded Heart of God: The Asian Concept of Han and the Christian Doctrine of Sin Wounded God, ${ }^{11)}$ Andrew Sung Park propounds that the Han can be resolved only by double and reciprocity. The wrongdoers once repented, they ask God heavenly forgiveness and the victim earthly forgiveness. At the same time, the victim's sorrow once comforted and he will forgive the wrongdoers. Han is unique in Korean culture, because we have been historically oppressed and the injustice was accumulated. I have discovered the book, 'Ethics and Moral Education in Jeju (제주의 윤리문화와 도덕교육)' by Kang Bong Soo, ${ }^{12)}$ who studied Jeju's Shamanism and asserted triple resolution for Jeju people' Han; first via the Heaven's Will and mandate, second by the World's morality and justice and third by egalitarianism, the preferential treatment for the poor. From these suggestions by two scholars from different religio-spritual traditions, individual HwaByung and the collective Han can be treated and even prevented, when these suggestions are applied appropriately.

However, I draw my reader's attention to the abuse of religious doctrines in order to avoid unwanted consequences. Take an example, in the novel by Lee Chung Joon; ${ }^{13)}$ ' $A$ Story of Worms (벌레 이야기)'. The doctrine of forgiveness begot a tragic suicide of the mother, whose right to forgive was taken away by the wrong interpretation of the doctrine.

From this brief survey of cultural syndromes in Korea and other world, I have discovered there are three consequences; 1) Healed and Readjusted, 2) Paradigmatically shifted for the better results and 3) Mal-adjustment for the worse. When a person are challenged by these predicaments (Han, Oppression and Injustice), he or she makes adjustments to overcome them. We find these examples in Robison Crusoe and the movie, Home-alone. The others could make a shift paradigmatically as seen in the cases in Jesus, Buddha, St. Augustine and Confucius. However, one may end up tragic events such as in divorce, depression, psychoneurosis and suicide. As it was fictionalized in a novel, 'I am a Cat (나는 고양이로소이다)' by Nazme Soseki, ${ }^{14)}$ an egoist becomes self-centered person, Isolated and self-control of own life, ending to suicide \& homicide. Of course, we prefer "Healed and Readjusted and Paradigmatically shifted for the better results" to "Mal-adjustment for the worse".

I realize that this short survey is loosely inclusive and not by an expert of anthropology, because I am simply a pediatrician-allergist-ethicist-turned-into-geriatrician-and-teacher. In the hope to let the culture shifted toward better one, I propose to allow our Korean culture to be educated. "How is it possible?", since the culture historically is formed and resilient and hard to change, you may ask. I have found it is possible in the fiction by Park Wansoe's novel, ${ }^{2}$ ) "After all, both girl and boy will carry equally the genetic connection. If we say that immorality is realized by our children, the difference of the sexes is only culture-dependent (결국 아들에 의해서나 딸에 의해서나 자기 핏줄은 오래도록 이어 진다고 봐야죠. 후손을 통해 자기생명이 영원히 이어지기 를 바라는 게 인간의 본능이라면, 남녀라는 성은 어디까지 나 껍데기고 문화일 뿐이죠)". She wrote prophetically via a second person with two daughters to tell the narrator, who had regretfully undergone artificial abortion to avoid third baby daughter. Culture is a social product which has been manufactured, therefore malleable for change when it is harmful.

Such hopeful possibility was asserted by Carl Rogers, ${ }^{15)}$ who claimed that public education could improve our culture for the better. He began his study as a seminary student for 2 years, and later he devoted his life for psychology of education. Rogers is known for practicing "unconditional positive regard", which is defined as accepting a person "without negative judgment". He called this as "Coherence". Second virtue for better education is "Benevolence". He sees the possibility of World Peace by humanistic approach in education. "The best vantage point for understanding behavior is from the internal frame of reference of the individual.

I draw another support for my claim from M. Scott Peck, ${ }^{16)}$ an American psychiatrist. His book, "Road less traveled" was well received. Road less traveled and two more books (a trilogy) for 10 year's span begin with sentences like, "Life is difficult", and "Life is complex". His book, The Different Drum: Community Making and Peace describes that Peck started the Foundation for Community Encouragement (FCE) to promote the formation of communities and better culture, which, he argues, are a first step towards uniting humanity and saving us from self-destruction. Culture of the people can be educated even to prevent culture syndrome, I assert.

Now, it is up to us to heal the cultural syndromes; I mean "to cure and care those patients with cultural syndromes".

\section{CONCLUSION}

I have surveyed the cultural syndromes, mainly Korean contrasted with other cultures. There are three consequenc- 
es; Better adjusted, Paradigm shift and maladjusted. Lastly I proposed a possible way to heal our culture to prevent the cultural syndromes by educating us to build the culture for better future.

\section{REFERENCES}

1. Adamson Hoebel E. [cited 2019 Nov 28]. Available from: https:// en.wikipedia.org/wiki/E._Adamson_Hoebel

2. Park W. 'Dreaming in an Incubator'. Hyundae Munhak, Republic of Korea, 1993.

3. Lin KM. Hwa-Byung: a Korean culture-bound syndrome. Am J Psychiatry 1983;140:105-7.

4. Min SK. Hwabyung in Korea: Culture and dynamic analysis. World Cultural Psychiatry Research Review 2009;4:12-21.

5. Scott Peck M. Road less traveled, character disorder. [cited 2019 Nov 28]. Available from: https://en.wikipedia.org/wiki/M._Scott_ Peck

6. The Identity Crisis of Erikson in Eight Stages of Man [cited 2019 Nov 28]. Available from: https://www.google.com/search? source $=\mathrm{hp} \& \mathrm{ei}=\mathrm{yznfXeaLKoTnwQPrnYdo \& q}=$ erik + erikson + $8+$ stages\&oq=Erik+eri\&gs_l=psy
7. Marcel G. Homo Viator, 1945. [cited 2019 Nov 28]. Available from: https://en.wikipedia.org/wiki/Gabriel_Marcel

8. Jones J. A charismatic cult leader died in mass suicide, 1978 in Guyana. [cited 2019 Nov 28]. Available from: https://en.wikipedia. org/wiki/Jim_Jones

9. Koresh D. A charismatic cult leader died in mass conflagration, 1993 in Texas. [cited 2019 Nov 28]. Available from: https://en.wikipedia.org/wiki/David_Koresh

10. Frankl V. Men's Search for the Meaning, 1946. [cited 2019 Nov 28]. Available from: https://en.wikipedia.org/wiki/Man\%27s_ Search_for_Meaning

11. Park AS. The wounded heart of God: The Asian Concept of Han and the Christian Doctrine of Sin. Abingdon, Nashville, TN, USA, 1993.

12. Kang BS. 'Ethics and Moral Education in Jeju'. Nuri, Republic of Korea, 2009.

13. Lee CJ. 'A Story of Worms'. Simji, Republic of Korea, 1988.

14. Soseki N. 'I am a Cat'. The Open Books co., Republic of Korea, 2009.

15. Rogers CR. On Becoming a Person: A Therapist's View of Psychotherapy. Houghton Mifflin Company, New York, USA, 1961.

16. Scott Peck M. The Different Drum: Community Making and Peace. Touchstone Books, London, UK, 1987. 